\title{
Erratum to: Quantitative assessment of the effect of FGFR2 gene polymorphism on the risk of breast cancer
}

\author{
Chengyou Jia $\cdot$ Yu Cai $\cdot$ Yushui Ma
}

Da Fu

Published online: 14 May 2010

(C) Springer Science+Business Media, LLC. 2010

Erratum to: Breast Cancer Res Treat

DOI 10.1007/s10549-010-0872-5

Unfortunately the first author's name had been misspelled. The correct version is Chengyou Jia and not Chenyou Jia as published.

The online version of the original article can be found under doi:10.1007/s10549-010-0872-5.

C. Jia

Department of Biochemistry, Shanghai Medical College, Fudan

University, Shanghai 200032, People's Republic of China

C. Jia

School of Life Sciences, Shandong University of Technology,

Zibo 255049, People's Republic of China

Y. Cai · Y. Ma · D. Fu (ه)

Department of Gastroenterology, Zhongshan Hospital, Fudan

University, 180 Feng Lin Road, Shanghai 200032, People's

Republic of China

e-mail: superdafu@ hotmail.com 